\title{
RELATIVE PROFITABILITY OF MAIZE PRODUCTION UNDER DIFFERENT FARM SIZE GROUPS IN KISHOREGONJ DISTRICT OF BANGLADESH
}

\author{
H. Uddin', M. H. A. Rashid ${ }^{2}$ and S. Akhter ${ }^{3}$ \\ Department of Agricultural Economics, Bangladesh Agricultural University \\ Mymensingh-2202, Bangladesh
}

\begin{abstract}
ABSRTACT
This study was conducted to estimate the relative profitability of Maize production under different farm size groups. Data were collected from randomly selected 74 maize growing farmers of which 25 were small, 32 were medium and 17 were large considering the scope and potentials of maize production at Kishoregonj district. To achieve the objectives of the study, descriptive statistical techniques such as sum, average, standard deviation etc, were used. The major findings of the study showed that per hectare average total costs were Tk. 30,147.54, Tk. 31,892.00 and Tk. 34,059.00 for small, medium and large farmers, respectively. Per hectare gross return from maize production were Tk. $61,730.00$, Tk. 79,716.00 and Tk. 75,707.00 for small, medium and large farmers, respectively. Per hectare gross margins from maize production was estimated at Tk. 36,836.00, Tk. 53,096.00 and Tk. 46,871.00 for small, medium and large farmers, respectively. Per hectare average net returns of maize were estimated at Tk. 31,583.00, Tk. 47,823.00 and Tk. 41,648.00 for small, medium and large farmers, respectively. The findings of the study revealed that medium farmers earned higher profit than those of small and large farmers.
\end{abstract}

Key Words: Profitability, Comparative, Maize farming, Farm size

\section{INTRODUCTION}

Maize is one of the most important food grains in the world as well as in developing countries. It supplies human food, feed and fodder for animal, fuel for domestic use and also raw material for use in industry. The commercial production of maize started in the early 1990's and since then it is booming and has become a major cash crop. Bangladesh grows moderate quantities of maize which can not meet domestic demand. However, there is a huge potential for production increase. Bangladesh has 14.09 million hectares (ha) of cultivated land and it is estimated that nearly 2.8 million ha are suitable for maize cultivation. At present the area under maize cultivation covers only 45,000 ha.

\footnotetext{
1 Ex-Postgraduate student, Department of Agricultural Economics, Bangladesh Agricultural University, Mymensingh-2202, Bangladesh

2 Professor and ${ }^{3}$ Lecturer, respectively, Department of Agricultural Economics, Bangladesh Agricultural University, Mymensingh-2202, Bangladesh
} 
In Bangladesh, the demand for maize has increased in recent years due to expansion of poultry and livestock industries. Local demand of maize stands at an estimated 1,200,000 tons annually, and this demand is mostly from the poultry and fish sector. Local production is only about 400,000 tons and the rest is imported. If the present rate of growth of poultry industry continues, demand for maize will be increased during the coming year. If we were able to diversify our rigid food habit from rice to maize then it would probably be possible to reduce food shortage to a greater extent.

Worldwide maize is the most widely grown cereal crop. Among the world's cereal crops, maize ranks second to wheat in production. However, among the developing countries maize ranks first in Latin America and Africa but third after rice and wheat in Asia (Dowswell et al., 1996), though quantitatively it is after wheat and rice it occupies the first position for its yield per unit area. The average grain yield of maize in the world is 4.43 tons per ha as compared to 3.91 tons per ha and 2.73 tons per ha of rice and wheat, respectively (FAO, 2002).

Maize has similar calorie content like wheat and rice. It is a more efficient source of energy than wheat for poultry birds. In terms of protein, carotene and oil content, maize is much better than rice. It may be mentioned here that with the poor quantity of protein in rice, more than 80 percent of the protein requirement is met by rice in Bangladesh. It is obvious that if rice is partially replaced by maize in the diet, protein intake will be increased.

The production of maize in Bangladesh is not good. But in recent years, poultry farms are using wheat instead of maize as poultry feed mainly because of inadequate and interrupted supply of maize. So, there is a great opportunity for expansion of maize cultivation.

However, during the last few decades maize area has increased by more than eighteen times while production has increased by about 74 times. The area under maize cultivation during 2006-07 was about 12339 ha with a total production of about 850000 metric tons and yield of $6780 \mathrm{~kg} / \mathrm{ha}$ (BBS, 2006). During the period from 1984-85 to 2006-07 maize production has increased from only 3270 metric tons to 850000 metric tons. Maize has a great prospect in Bangladesh. Production strategies require to be formulated in a manner so as to enable the families to increase food production and concurrently face other problems like feed, fodder and fuel shortage. The rate of adoption and sustainability of maize depends upon its economic profitability. Economic viability is one of the important criteria for assessing the suitability of a new crop technology.

In agriculture community of Bangladesh, maize farmers are not very aware of the benefits of maize cultivation and are afraid to invest in maize cultivation due to insufficient information on maize farming and marketing techniques. While making production decision, they consider costs of production against the yield of the crop since the farmer in rural setting are often victims of risk and uncertainty. However studies about the profitability of maize considering the different farm size groups are very few. 
Therefore the present study was conducted to estimate relative profitability of maize production under different farm size groups. The study also aimed to formulate some policy implications based on the findings of the study.

\section{MATERIALS AND METHODS}

Three villages under Pakundia thana of Kishoreganj district namely: Narandi, Pakundia and Hossendi were selected purposively to achieve the objectives of the study. Data were collected from the sample maize farmers through direct interviews using a set of structured and pre-tested questionnaire. From a list of maize farmers found from Upazila agricultural office a sample of 74 (small 32, medium 25 and large 17) farmers were randomly selected which constituted $23 \%$ of maize farmers of the study areas. All the collected data were then edited and it was converted into standard international units from local units. Both tabular and statistical analyses were used in the present study. The descriptive statistical techniques like the sum, average, percentage were used to find out profitability of different categories of farmers.

The following profit equation is used to find out the profitability of maize production. $\pi=\mathrm{Py} \cdot \mathrm{Qy}+\mathrm{P}_{\mathrm{b}} \mathrm{Q}_{\mathrm{b}}-\Sigma\left(\mathrm{Px}_{\mathrm{i}} \cdot \mathrm{X}_{\mathrm{i}}\right)-\mathrm{TFC}$

Where,

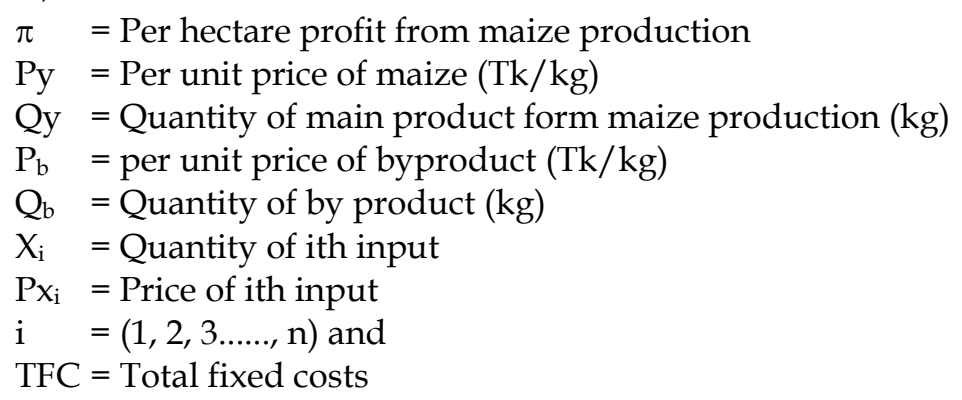

Gross margin was calculated using the following formula :

Gross margin $(\mathrm{GM})=$ Gross return $(\mathrm{GR})-$ Variable cost $(\mathrm{VC})$

\section{RESULTS AND DISCUSSION}

\section{Cost of maize production}

Production costs means the expenses incurred in producing output. Costs of any input used for producing an enterprise play a vital role. The major cost items of maize production included were human labor, power tiller, seeds, fertilizer, insecticides and irrigation. In this study, the total costs per hectare of maize production were worked out. Here variable and fixed costs were calculated separately. Table 1 presents per hectare costs of maize production for small, medium and large farmers separately. 


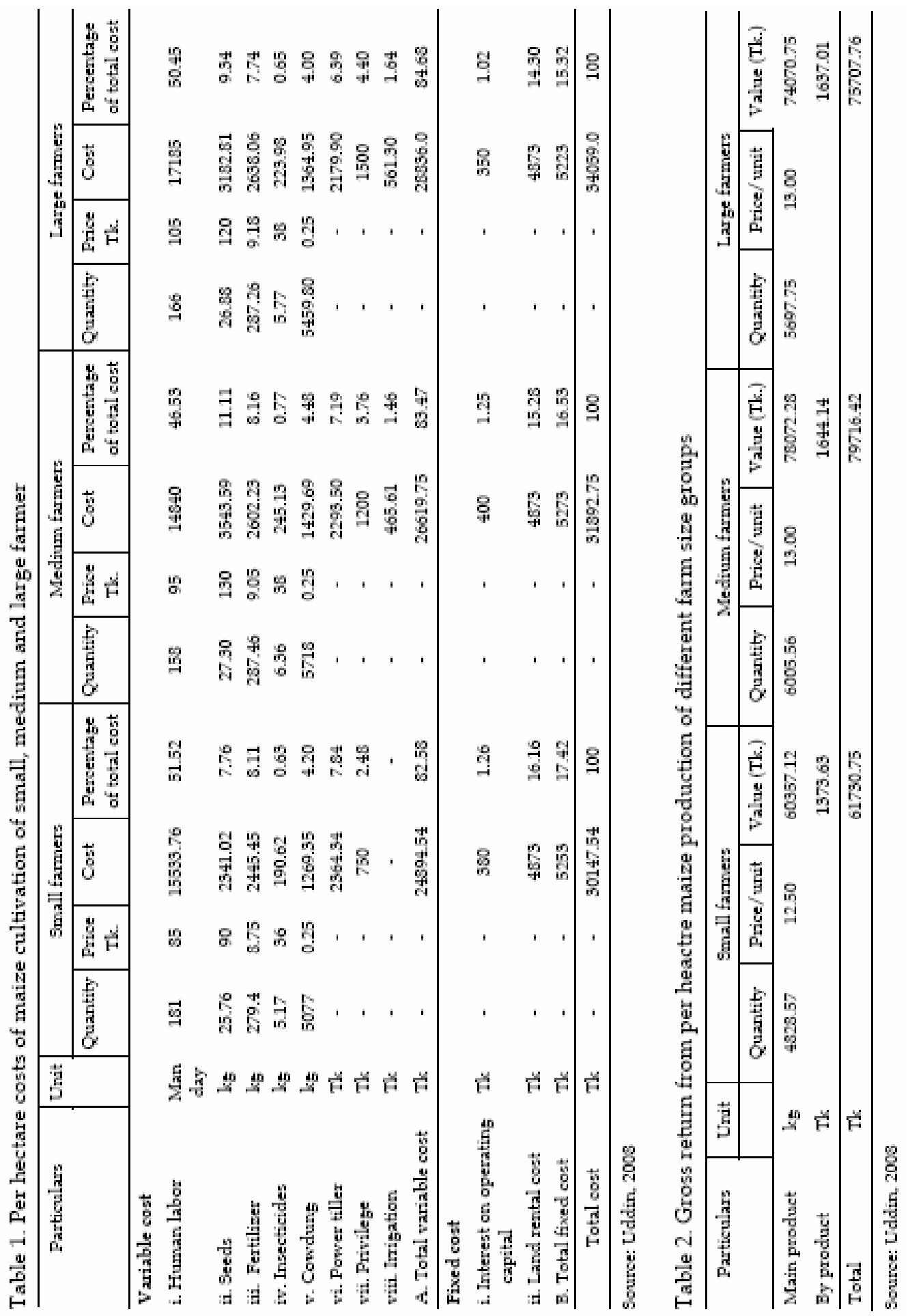


On an average, total cost of per hectare maize production was estimated at Tk. 30147.54, Tk. 31892.75 and Tk. 34059.00 for small, medium and large farmers respectively. The average variable cost of per hectare of maize production was estimated at Tk. 24894.5, Tk. 26619.75 and Tk. 28836.00 for small, medium and large farmers respectively. Human labor cost was the largest cost items of maize production for the all categories of farmers. This cost shares 51.52, 46.33 and 50.45\% for small, medium and large farmers respectively. Hence, one of the main opportunities for increasing profit is to low human labor cost. Seeds cost shared 7.76, 11.11 and $9.34 \%$ of total costs for small, medium and large farmers respectively. Fertilizer costs also shared 8.11, 8.16 and 7.74\% for small, medium and large farmers. And the average total fixed cost was estimated at Tk. 5253, Tk. 5373 and Tk. 5223 for small, medium and large farmers respectively. Fixed cost included interest on operating capital and land rental cost. Land rental cost shared $17.42,16.53$ and $15.32 \%$ for small, medium and large farmers which indicate that it is an influential cost of maize production.

\section{Return from maize production}

Gross return from maize production was defined as the sum of the returns from maize grain and its by-product. Total gross return from maize production (including value of the by product) was Tk. 61730/ha, Tk. 79716/ha and Tk. 75707/ha for small, medium and large farmers respectively. Shares of main product and by-product to the gross return were $96 \%$ and $4 \%$, respectively (Table 2). Gross margin is defined as the difference between gross return and variable costs. Table 3 reveals that per hectare gross margins from maize production was estimated at Tk. 36836, Tk. 53096 and Tk. 46871 for small, medium and large farmers respectively. Interest on operating capital, rental value of land etc. were excluded. Net return was obtained by deducting all cost (variable and fixed) from gross return. Table 3 reveals that per hectare net returns of maize were Tk. 31583, Tk. 47823 and Tk. 41648 for small, medium and large farmers respectively.

Table 3. Gross margin and net return from maize production

\begin{tabular}{l|c|c|c|c}
\hline \multicolumn{1}{c}{ Particulars } & Unit & Small & Medium & Large \\
\hline Gross return & Tk & 61730.75 & 79716.42 & 75707.76 \\
Variable cost & Tk & 24894.54 & 26619.75 & 28836.0 \\
Gross margin & Tk & 36836.21 & 53096.67 & 46871.76 \\
Net return & Tk & 31583.21 & 47823.67 & 41648.76 \\
\hline
\end{tabular}

Source: Uddin, 2008

\section{CONCLUSION}

Although maize is a relatively new crop in Bangladesh but it has an enormous market potential as well as its production is highly profitable. All categories of farmers are making profit in the study area. From the statistical evidence it was found that profit earned by medium farmers is high compared to large and small farmers. It was also found from the survey that small and large farmers used more human labor compared to 
medium farmers. Efficient use of improved techniques of production coupled with better management of land through increased institutional and infrastructural support will help enhance maize production.

\section{REFERENCES}

BBS, 2006. Statistical Yearbook of Bangladesh, Dhaka. Ministry of Planning, Government of the People's Republic of Bangladesh.

Dowswell, C. R., Paliwal, R. L. and Cantrell, R. P. 1996. Maize in the third world. Boulder, Colorado; Wistview Press. p. 1-2.

FAO, 2002. FAO Bullection of Statistics. Food and Agricultural Organization of the United Nations, Rome, Italy. 3(1): 20-31.

Uddin, H. 2008. An economic study on maize production under different farm size groups in a selected area of Bangladesh. Unpublished M. S. Thesis, Department of Agricultural Economics, Bangladesh Agricultural University, Mymensingh. 